"Mircea cel Batran" Naval Academy Scientific Bulletin, Volume XX - 2017 - Issue 2

The journal is indexed in: PROQUEST / DOAJ / Crossref / EBSCOhost/ INDEX COPERNICUS/ OAJI / DRJI I

JOURNAL INDEX / I2OR / SCIENCE LIBRARY INDEX / Google Scholar / Academic Keys / ROAD Open Access I Academic Resources / Scientific Indexing Services / SCIPIO/ JIFACTOR

\title{
COMPOSITION OF A NAVAL PENTATHLON MISSION
}

\author{
Virgil ENE-VOICULESCU ${ }^{1}$ \\ Carmen ENE-VOICULESCU ${ }^{2}$ \\ Alexandru ABRAMIUC ${ }^{3}$ \\ ${ }^{1}$ Professor Ph.D., Naval Academy, Constanta, Romania \\ ${ }^{2}$ Professor Ph.D., "Ovidius" University, Constanta, Romania \\ ${ }^{3}$ PhDc, Doctoral School, UNEFS Bucharest, Romania
}

\begin{abstract}
Absract:Naval Pentathlon is an individual, male and female, competition consisting of the following five events: obstacle race, lifesaving swimming race, utility swimming race, seamanship race, amphibious crosscountry race. An "Individual champion" is determined by the overall result in the five events. The team champion is determined by adding the individual results of a country's team. The regulations prescribe the way a CISM military world championship shall be conducted. On continental and local level, alterations can be made if it meets the needs of the organiser and the participants. These alterations have to be approved by the PTC before invitation is sent out to the participating countries. These regulations are based on CISM Regulations of Procedure (RP).
\end{abstract}

Keywords: naval pentathlon, events, CISM, mission

\section{GENERAL REGULATIONS}

\subsection{Composition of a naval pentathlon mission}

A complete mission shall be composed as follows: Chief of Mission (1), Team Captain/Manager (1), Coach Naval Pentathlon male (1), Coach Naval Pentathlon female (1), Competitors Naval Pentathlon male (5), Competitors Naval Pentathlon female (3), Ad libitum (1). Total: 13.

\subsection{Extra personnel}

Extra personnel can be brought to a competition after notifying the organizer. Such extra personnel are not included in the list above. TC members are considered extra personnel for a country's mission.

\subsection{Additional personnel}

No additional personnel may be included in the mission without the specific authorization of the sponsoring nation.

\subsection{Visitors/Spectators/Supporters}

The Chiefs of mission in attendance at the preliminary meeting may submit a list of personnel (in addition to their own mission) authorized to enter the area reserved for the Countries/competitors.

\subsection{Agenda of the competitions}

The duration of a competition is nine days. On the first day a member of the Technical Committee (TC), designated by the President (PTC), will check all courses, organisation, equipment, boats and craft to inspect and acknowledge the fulfilling of these regulations. A typical schedule is as follows:

\subsection{Sports management}

\subsubsection{ORGANISING COMMITTEE}

One organizing committee has to be established to prepare and run the championship. It is preferably made of nationals of the host country. It should be established not later than two years before the championship and co-operate closely with the CISM permanent secretary in Brussels and the TC president. The organising committee is responsible for the management of the Championship, which includes:

- Responsibility for all official actions taken for the task of organizing this championship.

- Appointment of various commissions and definition of their duties.

- Stating a working schedule of preparations and work before, during and after the competitions.

- Organization of a general secretariat of the competition.

- Continuously updating and informing the potential participating countries.

- Preparation and sending out of invitations (see "invitation file" in appendix)

Chairman of the organizing committee is preferably the commander of the base who organizes the competition. During the championship the Chairman should co-operate closely with the CISM official representative and the TC president.

\subsubsection{SUB-COMMITTEES}

The organizing committee appoints subcommittees for conducting various duties. The chairman of a subcommittee should be a member of the organizing committee. Two Management sub-committees must be established:

- The General Secretariat Sub-Committee.

- The Naval Pentathlon Sub-Committee

These sub-committees can be established:

- Information and PR

- Financial

- Logistic

- Transportation

- Sponsor

- Liaison office 
"Mircea cel Batran" Naval Academy Scientific Bulletin, Volume XX - 2017 - Issue 2

The journal is indexed in: PROQUEST / DOAJ / Crossref / EBSCOhost/ INDEX COPERNICUS/ OAJI / DRJI I JOURNAL INDEX / I2OR / SCIENCE LIBRARY INDEX / Google Scholar / Academic Keys / ROAD Open Access I Academic Resources / Scientific Indexing Services / SCIPIOI JIFACTOR

Additional Sub-Committee may be appointed as necessary.

\subsubsection{Naval Pentathlon Sub-Committee}

A Composition.

The Naval Pentathlon Sub-committee shall consist of qualified military or civilian personnel. The number of members shall be at the discretion of the Chairman of the Organising Committee. It $\mathrm{m}$ ay include international officials and judges if deemed necessary.

B Function.

The Naval Pentathlon Sub-committee shall be responsible for the technical preparation and direction of the Naval Pentathlon events.

Technical preparations include:

Arrangements, tracks, equipment and installations in accordance with the Naval Pentathlon regulations.

- Provision of the special equipment, stopwatches, whistles, flags, markers etc.

- Schedule of training and demonstrations, etc.

Management preparations include:

- Ensuring that special CISM-regulations are followed.

- Appointment and instruction of officials in charge of each of the Naval Pentathlon events and result service.

- Supervision of assembling the starting order and results for each event.

- Judging and classifying the various questions/problems in events, etc.

\subsection{Juries}

A. Jury of Appeal: See CISM RP. Part 1.

B. Technical Jury for Naval Pentathlon ( TJ ): See CISM RP.

\subsection{Language}

English is the original language used in the preparation of these regulations. This regulation is translated in to French, Spanish and Arabic.

\subsection{Tests}

\subsubsection{ANTI DOPING CONTROLS}

Doping is strictly forbidden in CISM, and particularly in NAVAL PENTATHLON. Anti Doping Controls will be carried out according to the CISM Anti Doping Regulations, Chapter IV, CISM Policy Manual, and they will also take into account the Anti Doping regulations of the International Federation. The number of tests to be done at the concerned championship in each event will be decided between the organiser, the CISM Official Representative and the President of the Technical Committee. As a minimal basis in our sport, ten (10) of controls should be carried out. Five (5) controls for mail and five (5) controls for female competitor.

\subsection{Titles and awards}

The official awards for Naval Pentathlon Championships shall be as follows:
1.10.1. NAVAL PENTATHLON PERMANENT TROPHIES

One perpetual challenge trophies exist:

For the Naval Pentathlon, a silver cup is presented by the Italian Navy. The trophy is awarded to the nation winning the team championship; "CISM team Naval Pentathlon Champion". The above challenge trophies are presented in addition to the CISM prizes. Nations holding this trophy for a year must perform any necessary upkeep, have the results of that year engraved and return the trophy in good condition to the host nation prior to the next competition.

1.10.2. MEDALS

The following CISM-medals (Gold, Silver and Bronze) shall be presented by the sponsoring nation.

Team medal

To all competitors and coach of the first, second and thirds placed teams, male and female (six/four gold, six/four silver and six/four bronze). Individual medal

To the individual competitor in first, second and third overall places, male and female.

Other prizes or awards are optional and at the discretion of the sponsoring nation.

1.10.3 FAIR-PLAY CUP

The PTC will, if appropriate, award an individual or team this "Fair-Play" title after the championship. Nominations must be made to the president in writing before the PTC enlarged meeting.

\subsection{Miscellaneous}

1.11.1 AMENDMENTS OF THE REGULATIONS During the championship there will be a public TC enlarged meeting (see CISM RP). The presence of one representative per competing nation is required in the event of amending the sports regulations or completing the calendar. The TC will be authorized to amend issues of limited technical impact by the majority of the TC members. A Chief of mission or the TC must introduce any proposed amendment to the regulations. The amendment proposed must be addressed to the TC President in writing. He will examine the proposition and give his technical opinion to CISM Permanent Commission for Sports.

\section{NAVAL PENTATHLON REGULATIONS} INTRODUCTION

These regulations describe the conduct of naval pentathlon championships on the world and continental level. For regional and local events exemptions from these regulations can be decided if it meets the requirements of the organiser and athletes. These exemptions can be the order in which the events are held, the type of rifle that will be used, the type of working dress that will be used, the amount of lanes used, and the starting procedure in the last event. In the 


\begin{abstract}
"Mircea cel Batran" Naval Academy Scientific Bulletin, Volume XX - 2017 - Issue 2
The journal is indexed in: PROQUEST / DOAJ / Crossref / EBSCOhost/ INDEX COPERNICUS/ OAJI / DRJI I JOURNAL INDEX / I2OR / SCIENCE LIBRARY INDEX / Google Scholar / Academic Keys / ROAD Open Access I Academic Resources / Scientific Indexing Services I SCIPIOI JIFACTOR
\end{abstract}

regulations, measurements or sums for female competitors are indicated after a slash or with an $\mathrm{F}$.

\section{COMPETITORS}

A complete team of five males/three females (5/3) competitors should represent each nation. The four/two (4/2) highest scoring competitors of each nation shall be "counting members" of the team. If the nation enters a team of four/three (4/3) or less competitors it will be considered a team under the above mentioned restrictions. Only competitors of a country's team will be considered in determining the individual champion. If the number of competing countries in Naval Pentathlon is to be more than twenty (20), the sponsoring nation can limit the ad libitum participants._Information detailing these limitations must be sent out to the participating countries two (2) months before the competitions starts.

\section{STARTING ORDER}

The order in which the athletes will start is based on the quality of the performance of the athlete. A starting list will be prepared by the organiser, supervised by a TC member, based on the information given from the Chief of delegation (see appendix). This information has to be based on the athlete's previous result in a major championship (or, in the event of a first time competitor, the final other team competition) following these regulations. The organiser will then prepare a starting list where the athletes with the best performances will start in the end of each event (exemption Seamanship Race and Amphibious c-c Race). The athlete with the best result will start on the centre lane in his heat. The athlete with the second best result will start on the left lane of the centre. The athlete with the third best result will start on the right lane of the centre and so on. In Seamanship Race the conditions may require that the athlete with the highest quality in performance start in the beginning or in the middle. The organiser and the TJ, supervised by the TC will decide this. In Amphibious cc Race; the starting order will be determined based upon the overall individual standings at the end of four (4) events. The athletes with the most points will then race in the last heat. If possible the organiser can start the athletes of the final heats in Amphibious cc Race with "handicap start". This will then be based on the athletes' points after four (4) events. The start time of a heat should be indicated in the starting list by a specific start time for each heat.

DETERMINATION OF INDIVIDUAL CHAMPION

In each event of the Naval Pentathlon an individual competitor shall be awarded points based on his time to complete the event (see scoring tables in Appendices). After the completion of all events the individual's place shall be determined by adding up the points obtained in each event, the winner being the one with the highest number of points. In event of a tie in points, after all events have been totalled, the individual with the best time in the Seamanship Race shall take precedence (the time must be corrected with eventual penalties). The individual competitor with the most points after five (5) events shall be declared the individual "CISM Champion".

\section{DETERMINATION OF TEAM CHAMPION}

After the completion of all events the place of each team shall be determined by adding the points obtained by the four/two (4/2) highest placed team-members in the individual overall result. If there is a tie between teams, the team with the best total time of these four/two (4/2) team-members obtained in the Seamanship Race shall take precedence. The team with the most points after five (5) events shall be declared "CISM Champion".

\section{STARTING OF RACES}

It is up to the competitor to be ready to start when the start signal is given. Races shall be started in accordance with the following sequence. At the "final call" the competitor shall be standing - ready for start - behind the "first" line - or start block. On the first whistle (low and long) the competitor moves to the "first" line - or enters the back of the block. On the command "on your marks" the competitor moves forward to the starting line - or to the front of the block - and gets as soon as possible in to his starting positions. When the competitors are standing still the start will be given by pistol or acoustic signal device. The start shall not be given before the preceding competitor or competitors have crossed the finish line or have left the track. Exemptions see Amphibious cc Race.

\section{FALSE STARTS}

There will be not more then two (2) starts in one heat. The competitor that makes a false start at the second attempt will receive a penalty of 50 points in this event, but the start will be valid for the all competitors. The referee will warn any competitor marking a false start.

\section{TIME KEEPING}

Using of electrical time keeping is preferable. Otherwise, for each competitor, there must be three (3) separate timekeepers. If the time of two (2) timekeepers is the same, that will be the official time of the race. If all three (3) times are different, the middle time will be valid. Readings in $100 d s$ of a second will be of no concern.

\section{RECORD REGISTRATION}

Due to differences of courses, pools, and equipment, official records will not be registered. Winning times and names for each event will be registered on a yearly basis in an appendix in these regulations. 


\begin{abstract}
"Mircea cel Batran" Naval Academy Scientific Bulletin, Volume XX - 2017 - Issue 2
The journal is indexed in: PROQUEST / DOAJ / Crossref / EBSCOhost/ INDEX COPERNICUS/ OAJI / DRJI I JOURNAL INDEX / I2OR / SCIENCE LIBRARY INDEX / Google Scholar / Academic Keys / ROAD Open Access I Academic Resources / Scientific Indexing Services / SCIPIOI JIFACTOR
\end{abstract}

\section{PRACTISING}

The organiser must set up a training schedule (see appendix ) for all events and countries. This must take into consideration time for transportation, ceremonies and so on. Competitors shall be given at least two (2) opportunities to try out each course before the competition starts. Each course shall be outfitted, as it will be at the competition. Necessary demonstrations shall be arranged during the training and just before (test runners) the start of the official competition.

\section{SPECIAL EQUIPMENT}

The use of spiked or nailed shoes is prohibited. The competitors may bring and use the following equipment as their own if it meets the specifications in these regulations: Working dress, heaving lines, fins, rifle and ammunition. Corresponding equipment and the rest of the equipment required will be arranged by the sponsoring nation and can be used freely among the competitors. The competitor is, however, responsible for the function of the equipment he uses.

\section{WORKING DRESS}

The working dress used in Live-Saving and Amphibious cross-country Race for male competitors will be inspected on the competitor prior to the competition with the team captains present and under the supervision of a member of the Technical Jury. The working dress (See Appendix) is organised by the competitor. It must be a working dress used in military service. It consists of a jacket and trousers. The dress shall be fitted out and used as follows:

- The clothes shall be fitted with the competitor dressed standing on the floor with his heels, arms, back, shoulders and head against a wall.

- The trousers must extend from the top of the hipbone to $12 \mathrm{~cm}$ above the floor. Relocating buttons and making the buttonholes larger is permitted, but additional buttonholes are not authorised.

- The jacket or shirt must extend $10 \mathrm{~cm}$ below the hipbone. Sleeves must reach the wrist bone with the arms in the down position. The upper most button (the button decided to be the first and buttoned button) shall be sewed together so that it can't be opened.

After the inspection (that means that the clothing of the competitor is acknowledged) the competitor's clothes will be marked and all the competitor's clothing will be locked up in one bag for each country. If the competitor fail the inspection it is up the own country to have spare working dress for re inspection.

The clothes must be worn in a "standard/ordinary" way during the fitting and during the race. Practice with these clothes cannot be arranged. The athlete may use his spare dress for practising. The working dress will not be supplied by the sponsoring nation.

\section{FINS}

Bi fins (one separate fin on each foot) are used. Size and form are optional. Mono fins are not allowed.

\section{HEAVINGLINES}

A traditional heaving line. Size and form are optional. The line must be free from aids of any kind.

\section{GRANADES}

Granades are provided by the sponsoring nation.(See Appendix)

\section{RIFLE}

The rifle used in amphibious is of specific standards and must meet the specified measurements. The rifle is specified in appendix.

\section{GENERAL RECOMMENDATIONS}

Tracks are built for right-handed people. It is recommended that each event of the Naval Pentathlon is arranged so that at least three (3), and in the case of the Obstacle Race two (2), competitors can compete at the same time. Care must be taken so that the length and standard of the entire course for each competitor is the same. In the Seamanship Race particular care must be given to the factors of wind, current and equipment to ensure that the competitors have equal tracks. The tracks must be separated by at least $12 \mathrm{~m}$. The organiser must provide at least two (2) boats per track. These must be assigned for each track in a fix way by drawing of lots (under the supervision of a member of the Technical Jury). Non authorised help from an outsider during a race is prohibited.

\section{JUDGES}

A judge shall have the necessary training and experience before the competition starts. Judges shall be stationed at places where rules specify an event has to be done in a particular way or penalty points or disqualification will result.

A judge will indicate a wrong passing or work by an immediate whistle blow (not in the Swimming events) and raising of a red flag. This should be done in the most obvious possible way to insure that the competitor easily can observe and understand the signals.

Decisions taken by a judge shall be put down in writing and handed over to the leader of current event.

Judges and officials must be present during the training, so that corrections of the track, performances and judgement can be made.

\section{PROTESTS}

Any protest must be submitted to one member of the Technical Jury (TJ) in writing and signed by the chief of mission or team captain not later then fifteen (15) minutes after the actual race. Each protest shall refer to the articles of these rules on which it is based. In accordance 
"Mircea cel Batran" Naval Academy Scientific Bulletin, Volume XX - 2017 - Issue 2

The journal is indexed in: PROQUEST / DOAJ / Crossref / EBSCOhost/ INDEX COPERNICUS/ OAJI / DRJI I

JOURNAL INDEX / I2OR / SCIENCE LIBRARY INDEX / Google Scholar / Academic Keys / ROAD Open Access I Academic Resources / Scientific Indexing Services / SCIPIOI JIFACTOR

with the CISM Regulation a protest requires a deposit of $\$ 100$.- ( USD) has to be paid by a team and must be given together with the protest to the member $\mathrm{TJ}$. If the protest is refused by the TJ and no appeal is made, the deposit will be forfeited and paid to CISM. If the protest is valid, the deposit will be repaid.

\section{BASIS FOR JUDGEMENT}

If a competitor, without trying to follow the regulations, passes an obstacle or feature there will be a 300 point penalty for this negligence. If a competitor unintentionally passes an obstacle or feature the wrong way he may try again without special penalty until he has succeeded or decides to leave it undone. Then there will be a specific time penalty for that obstacle or feature. If a competitor does not start or is forced to abandon an event or fails to finish the event for any reason he shall receive zero (0) points in that event. He may however be included in the general classifications and receive individual and team prizes. If a competitor is disqualified for having broken the rules of good sportsmanship he may not be included in any classification. He shall receive no prizes. A competitors performance will be judged in accordance to following basis:

- His performance is in accordance to the regulations.

* No action will be taken.

- He makes an error in a feature (e.g. steps on a line):

* A judge will indicate the mistake with a whistle blow and raising a red flag.

1. He corrects his error.
* No action will be taken.

2. He continues.

* He will have a penalty in accordance to the event's regulations.

NOTE: It is the competitor's responsibility to observe the signals from the judge.

- He is incapable of finishing the race.

* He will receive zero (0) points in this event.

- He is not capable of finishing the race before his elapsed time equals 0 points.

* He will receive zero (0) points in this event.

NOTE: The competitor has to clear the track when he has received the time of zero (0) points.

- He has by negligence performed the race in a way that is not in accordance to the regulations.

* He will receive zero (0) points in this event

- He is deliberately breaking "the rules of good sportsmanship".

He will be disqualified, and can not compete more in these present championships.

Errors, mistakes not foreseen in these regulations or effects depending on local circumstances will be judged by the TJ. The judgement can be a warning or a penalty of maximum 150 points, the competitor will have an opportunity to race once more, the result will stand or the rules of good sportsmanship have been broken. 